\title{
Non Agriculture with Settlement Legality in Boyolali Regency Central Java, Indonesia
}

\author{
Ahmad Kurniadi ${ }^{1}$, Isharyanto ${ }^{2}$ \\ ${ }^{1,2}$ Universitas Negeri Sebelas Maret, Surakarta, Indonesia \\ ahmadkurniadi999@yahoo.com
}

\begin{abstract}
This research has been done to identify changes in agricultural land to non-agriculture causing the establishment of illegal settlements. Viewed from the standpoint of nature this research is descriptive research, carried out in order to help in strengthening old theories or within the framework of developing new theories. Research locations are in the Office of the Regional Planning, Research and Development (BP3D) Boyolali Regency and Boyolali Regency Agriculture Office. Data collection was carried out by interview and literature study. Data analysis technique is done by data reduction, data display and conclusion. The results show that agricultural development will occur if land problems over the conversion of agricultural land into settlements are unavoidable or need to find a solution to a problem that is very urgent, this is by studying the impact of the problem and socializing the community over these impacts and their resolution to obtain clarity of land legality the conversion. When land starts to shrink, domestic food needs will decrease because population growth cannot be avoided every year. For this reason, immediate special handling is needed, such as direct counseling for the community. Will be danger of land conversion is carried out continuously. Development of the latest technology is needed to manage the land so that fertility does not decrease quickly so as to reduce land productivity. Another way replacement of agricultural land which is used as an alternative handling of the legality problem of conversion of agricultural land.
\end{abstract}

Keywords

non-agriculture; the establishment of illegal settlements

\section{Introduction}

Various effects of industrial activities make Boyolali Regency as a center for the collection of production results from its hinterland area and also vice versa, namely distributing things needed by its hinterland area. This development requires the fulfillment of various facilities to support various activities, ranging from residential to the area. With the establishment of industrial centers, it has attracted residents from other regions, especially coming from the countryside to fill the existing employment gaps in the new place and bring an imbalance (disequilibrium). This imbalance is a result of disparities in economic growth and employment opportunities that are always accompanied by striking demographic changes. ${ }^{1}$

The increase in population occurred due to the increased demand for space and infrastructure that filled the space to support the socio-economic activities of the urban population. The surrounding land will automatically change its function. Starting with the terminology Iwan Kustiwan, that land conversion is a function of land conversion which is

\footnotetext{
${ }^{1}$ Rochimin, Dahuri et al, 2004. Pembangunan Wilayah : Perspektif Ekonomi, Sosial and Lingkungan. Jakarta : LP3ES. P. 220 
generally related to transformation in the allocation of land resources from one use to another.

The value of the area's function and available land is the main prerequisite for urbanization that drives the socio-economic goals of the wishes of the community. Economic impetus is the main motive in the formation of a land use structure in the city with the emergence of strategic business centers. Besides business motives there are also political motives, the physical form of the city, such as topography, drainage and the like. The growth of the city will move dynamically according to the needs, potential, human culture, where the development starts from the existence of centers of activity as embryos growth centers ${ }^{2}$. there is built up land consisting of activities of settlements, industry, offices and commercial services that are running smoothly (urban sprawl), in accordance with the potential of the transportation network as a result of accessibility that forms a network pattern between growth centers that naturally considers land conditions which exists.

Changes that occur due to the pressure of socio-economic transformation, especially in the city center, bring inefficiencies and inefficiencies in the use of space. Economic impetus is the main motive in the formation of a land use structure in the city with the emergence of strategic business centers. Besides business motives there are also political motives, the physical form of the city, such as topography, drainage and the like. The growth of the city will move dynamically according to the needs, potential, human culture, where the development starts from the existence of centers of activity as embryos growth centers which is limited and influences aspects of city management. At the practice level, spatial and regional layout load deviations often occur. Another fact also shows that many forms of business without a business permit and location permit can operate without sanctions by the local government. So that economic oriented phenomena that have not been regulated by the government in its implementation still rely on public awareness to complement the emergence of strategic business centers. In addition to business motives there are also political motives, the physical form of the city, such as topography, drainage and the like. The growth of the city will move dynamically according to the needs, potential, human culture, where development starts from the existence of centers of activity as embryos of growth centers.

Indications that trigger the change in land use in Boyolali are:

1. In 2017 the population of Boyolali Regency was 974,579 people. According to 2016 BPS data, there are 963690 people with a growth rate of $0.54 \%$ per year. Judging from the rate of population growth, it can be indicated that socioeconomic activities are developing that demand housing and other urban service facilities are met.

2. The number of heavy and capital-intensive industries increased from 98 units in 2017 to 109 industries in 2017. This is related to the increase in population migration in meeting labor needs.

3. Land use for housing from condition data for 2012 - 1917 from 4,400.97 Ha to 6,223.38 Ha. This shows a decrease in agricultural land and turned into settlements.

4. From Boyolali Regency's GRDP in 2012-2017, the trade, hotel and restaurant sector grew from $3.95 \%$ to $8.53 \%$. This shows significant economic and spatial growth

Spatial plans (RTRW) Boyolali Regency as stipulated in Regional Regulation No. 9 of 2011 after obtaining Substantive approval from the Ministry ATR/BPN. In addition, the

\footnotetext{
${ }^{2}$ Koestoer, 2001Koestoer, Raldi Hendro. 1995. Perspektif Lingkungan Desa Kota: Teori and Kasus. Jakarta: UI. Press. P.32 
Governor of Central Java has also officially evaluated it so that it has been enacted today. Evaluation and review every five years.

The evaluation is carried out in order to follow the dynamics of the development of the strategic environment, the latest regulations and the alignment of various national strategic policy plans relating to utilization related to spatial use. The revision of this Regional Regulation on RTRW has an important meaning in encouraging progress in Boyolali through the growth of investment which is expected to have a positive effect on the growth of the regional economy and increase people's welfare. Spatial planning is the key to opening an investment before the next licensing process.

"The goal of spatial planning in Boyolali Regency is to realize integrated development in all regencies based on agriculture and the development of various industries with environmental insight," explained the Head of the Regional Planning, Research and Development Agency (BP3D) of Boyolali Regency, Nur Kamdani when met at his office on Wednesday (7/17/2019). Furthermore, according to Nur Khamdani, in Boyolali Regency thousands of hectares have been prepared to support the industry in Kota Susu. "To support the investment, the region has been prepared Industrial allotment (KPI) covering an area of 2,130 hectares spread across 19 districts, "he explained.

Based on the background description above, the authors are interested in studying more deeply with the title of the study " Non Agriculture with Settlement Legality in Boyolali Regency Central Java, Indonesia". The aim of this research is to identify changes in agricultural land to non-agriculture causing settlement establishment illegally.

GKA follows the dynamics of the development of the strategic environment, the latest regulations and the alignment of various national strategic policy plans related to utilization related to spatial use. The revision of this Regional Regulation on RTRW has an important meaning in encouraging progress in Boyolali through the growth of investment which is expected to have a positive effect on the growth of the regional economy and increase people's welfare. Spatial planning is the key to opening an investment before the next licensing process.

"The goal of spatial planning in Boyolali Regency is to realize integrated development in all regencies based on agriculture and the development of various industries with environmental insight," explained the Head of the Regional Planning, Research and Development Agency (BP3D) of Boyolali Regency, Nur Kamdani when met at his office on Wednesday (7/17/2019). Furthermore, according to Nur Khamdani, in Boyolali Regency thousands of hectares have been prepared to support the industry in Kota Susu. "To support the investment, the region has been prepared

\section{Review of Literature}

\subsection{Overview of Spatial and Regional Plans}

Preparation of city spatial plans refers to the National Spatial Planning and provincial spatial plans, guidelines and guidelines for the implementation of spatial planning and long-term regional development plans. Preparation of urban spatial plans must pay attention to the development of Regency problems and the results of the study of the implications of spatial planning of cities, efforts to equitable development and economic growth of the city, alignment of urban development aspirations, carrying capacity and capacity of the environment, long-term regional development plans, regional spatial plans bordering city, and the strategic spatial plan of the city. Spatial plans for urban areas contain the objectives, policies, and strategies for spatial planning of urban areas, plans for 
spatial structure of urban areas which include urban systems in the area related to rural areas and infrastructure systems for urban area networks, plans for spatial patterns of urban areas that include city protected areas and city cultivation area, determination of the city strategic area, directions for the use of urban area space which contains an indication of the main medium-term five-year program, and provisions for controlling spatial use of the city area that contain general provisions of zoning regulations, licensing provisions, incentive and disincentive provisions, and sanctions directives. Urban spatial plans become guidelines for the preparation of regional long-term development plans, preparation of medium-term development plans regions, spatial use and control of spatial use in urban areas, realizing cohesiveness, interconnection, and balance between sectors, determination of location and function of space for investment and spatial planning of strategic areas of the city

In addition to the limited land available, spatial issues are increasingly complicated, because the current condition of the Indonesian economy is accelerating. Space is the physical appearance of the region in geographical and geometric dimensions which is a container for humans to carry out their lives in a decent quality of life. What is meant by the structural form of spatial use is the arrangement of the elements that form the hue of the natural environment, the social environment, the artificial environment in a hierarchical relationship with one another. ${ }^{3}$

The term spatial is an objective reality. Structural form and spatial use patterns can be orderly and harmonious, can also be chaotic. Including that it must be understood that structural forms occur because of social, economic, technological, political and administrative processes. Benefits and functions should also mean those on the surface, subsurface and on the surface of the earth that are permanent. Can be in the form of buildings, fields, forests and others on the surface of the earth, it can also be a mine, bore wells, aquifers, etc. under the surface and flight routes, air transport, rain carriers, and others above the earth's surface. ${ }^{4}$

\subsection{Review of the Function of Agriculture to Non-Agricultural Land}

Population growth in an area is associated with an increase in land use change. An increase in population increases the need for developed land. Demand for land increases (Demand side) while land availability does not change (Supply side). Kondisi limited land resources while this high population growth causes the value of land to grow each year. This condition results in the contested land value between sectors. For example the value of land for agriculture is compared with the value of land for property / housing / industry. The value of land for industry and housing is much higher than the value of land for agriculture, especially rice fields. Because the direct benefits received by agricultural land are smaller, land conversion will be easier. ${ }^{5}$ In the agricultural process through several stages in the process of managing agricultural resources. The first stage of agricultural process is the management of land (Pandapotan, 2019).

The process of land conversion cannot be avoided in every developing region. Developing areas usually have a fairly high population growth, followed by an increase in

\footnotetext{
${ }^{3}$ Ridwan and Sodik. 2016. Hukum Tata Ruang dalam Konsep and kebijakan Otonomi Daerah. Cetakan Ke 3. Bandung: Penerbit Nuansa. P. 22.

${ }^{4}$ Wirasaputri. Proses Penyusunan Rencana Tata Ruang dalam Kaitan Kelestarian Fungsi Lingkungan Hidup. Kanun Jurnal Ilmu Hukum. No. 62, Th. XVI (April, 2014), pp. 129-146. P.135

${ }^{5}$ Kusumastuti et al. 2018. Faktor Yang Mempengaruhi Alih Fungsi Lahan Pertanian Pangan Di Kabupaten Pandeglang. Jurnal Sodality: Jurnal Sosiologi Pedesaan | Vol 6 No 2 Agustus 2018, P. 131-136 | 135 
land requirements for settlements and other public facilities including industry. The process of land conversion usually begins with the release of land mainly due to the land sale process ${ }^{6}$

\subsection{Overview of the Government Control Function}

The process of land conversion cannot be avoided in every developing region. Developing areas usually have a fairly high population growth, followed by an increase in land requirements for settlements and other public facilities including industry. The process of land conversion usually begins with the release of land mainly due to the land sale process ${ }^{7}$.

Regional growth that drives up land prices can also trigger land release. In general, the transfer of function of agricultural land from farmers is influenced by three things. First, external factors in the form of regional growth dynamics, demographics and the economy. Secondly, internal factors are in the form of socio-economic conditions of families of land users. Third, policy factors, in the form of rules and regulations as well as the implementation of rules

A better understanding of the nature of public policy as an action that leads to a goal, when we can break down government policies into several categories, namely ${ }^{8}$

1. Policy demands

2. Policy decisions

3. Policy statements

4. Policy outputs

5. The final policy outcome

Entering the current economic recovery period, the government through the policy of the use of abandoned or abandoned land has sought to encourage owners and smallholders to jointly deal with cultivating their land with food crop commodities. This effort only temporary. With the improvement of investment capability, the developers or developers who have already mastered agricultural land (rice fields) will continue to try to carry out non-agricultural activities (services, industry, and housing) on the land.

This has further raised new problems in line with the implementation of regional autonomy. This problem is increasingly complex in the field because the direction of national policy in terms of controlling the conversion of agricultural land functions often collides with local government policies that prioritize local interests and regional policies. Although the application of land use control policies is still considered to be quite effective in limiting the use of lowland land for non-agricultural activities (such as the location licensing mechanism and the implementation of the Regional Spatial Plan), there are apparently many "land speculators" behaviors that are not affordable by the application of the policy.

1. There are many cases where the owners of agricultural land deliberately change the function of the land to make it easier to be traded without going through licensing mechanisms or violating existing Spatial Planning. Economic deregulation, driving Foreign Investment or Domestic Investment and promoting non-oil and gas

\footnotetext{
${ }^{6}$ R. Janah, B. T. Eddy and T. Dalmiyatun. Alih fungsi lahan pertanian and dampaknya terhadap Kehidupan penduduk di kecamatan Sayung Kabupaten Demak. Agrisocionomics Jurnal Sosial Ekonomi Pertanian. ISSN 2580-0566. 1(1):1-10, Mei 2017

${ }^{7}$ Ibid, R. Janah, B. T. Eddy and T. Dalmiyatun

${ }^{8}$ Taufiqurokhman. 2014. Kebijakan Publik. Fakultas Ilmu Sosial And Ilmu Politik Universitas Moestopo Beragama Pers. ISBN 602-9006-07-0. P. 6 
development (industry and property) have led to very real economic growth. But on the other hand as a consequence of the process of transformation of the economic structure (from agriculture to non-agriculture), in addition to changes in demographic aspects (rural to urban), this change has had a special impact on the survival of agricultural land (including irrigated rice fields).

2. In the context of development in Java, the number of families or households that live from the non-agricultural sector reaches $100 \%$. Some important factors that influence changes in the pattern of agricultural land use in Java are the privatization factors for the development of industrial estates, large-scale residential developments and new cities, as well as deregulation of investment and licensing facilities.

3. Three national policies that have a direct effect on the conversion of agricultural land to non-agriculture are: Changes in land use can be caused by changes in regional spatial plans, the direction of development policies and because of market mechanisms. In the past there were more because of the last two things, due to the lack of understanding of the community and government officials regarding spatial planning, or regional spatial plans that were difficult to realize. In line with the development policy which emphasizes the aspect of growth through the ease of investment facilities, both to local and foreign investors in the provision of land, the change in land use from agriculture to non-agriculture occurs widely.

4. Recognizing this problem, the government has established several provisions in the policy to limit and / or prevent the conversion of arable agricultural land to nonagricultural uses such as:

a. Presidential Decree Number 53 of 1989 concerning Industrial Estates and Presidential Decree Number 33 of Year 1990 oncerning the Use of Land for the Development of Industrial Estates has banned the development of industrial estates as well as the provision or permit of location and acquisition of land on arable land.

b. Letter of the State Minister for National Development Planning / Chair of Bappenas Number 5334 / MK / 9/1994 dated 29 September 1994 concerning Changes to Use of Technical Irrigated Rice Land for Non-Agricultural Land Use.

c. Letter of the State Minister for National Development Planning / Chairperson of Bappenas to the Minister of Home Affairs Number 5335 / MK / 9/1994 dated 29 September 1994 concerning the Compilation of the Second Regional Spatial Plan.

d. In the context of implementing PAKTO-23, a State Minister for Agrarian Affairs / Head of the National Land Agency sP.1 be issued to the Head of the Regional Office of the Provincial National Land Agency and Heads of District / City Land Offices throughout Indonesia Number 460-3346 dated 31 October 1994 concerning changes to the use of Technical Irrigated Rice Land for NonAgricultural Land Use. This circular prohibits Land Officers in the area from issuing location permits for irrigated land for non-agricultural purposes, even though according to the Regional Spatial Plan it is intended for non-agricultural activities.

\subsection{Licensing Review}

Law is a means in which contained values or concepts about justice, truth, and social benefits and so on. The legal content is abstract. Law enforcement is essentially the 
enforcement of these abstract ideas or concepts. Law enforcement itself is an attempt to turn these ideas into reality. ${ }^{9}$ Conceptual, then the essence and meaning of law enforcement lies in the activity of harmonizing the relationships of values that are set out in the rules that are steady and manifest and the attitude of action as a series of translation of the final stage of values, to create, maintain, and maintain social peace. Conception that has a philosophical basis, requires further explanation, so that it will look more concrete. ${ }^{10}$

Law enforcement activities are first intended to improve law order and certainty in society. In the framework of this effort, a system of coordination and harmonization of tasks between law enforcement agencies will be established. Efforts to uphold the law also include activities to increase public confidence in the law and its enforcers. ${ }^{11}$ The government uses permits as a juridical tool to control citizens' behavior. According to Spelt and Ten Berge, a permit is an agreement from the authorities based on laws or government regulations, in certain circumstances to deviate from the provisions of the statutory prohibition. Meanwhile Ridwan HR, by summarizing a series of opinions the scholars concluded that the permit is a one-sided government action based on legislation to be applied to concrete events according to certain procedures and requirements. Based on such understanding, the elements in licensing include juridical instruments, statutory regulations, government organs, concrete events, procedures and requirements.

As a decision issued by the government, permits can be used for certain purposes in the form of a desire to direct or control certain activities, prevent danger to the environment, a desire to protect certain objects, want to divide small objects, and can also be shown for direction, by selecting certain people and activities. ${ }^{12}$

As it is known from such a large area, a large population, then the regional expansion is done. As a consequence of the principle of decentralization, then various government affairs were handed over to the regions into regional affairs. The transfer of authority within the decentralization framework is intended to bridge the need for efficiency and effectiveness in handling problems, optimizing local roles, as well as accommodation for regional diversity. With this reality, the handling of licensing issues becomes one of the distribution, not only the authority of the central government but also the authority of the regional government.

\section{Research Method}

This research method is a descriptive study, carried out in order to help in strengthening old theories or within the framework of developing new theories. Explorative research is primarily intended not to test certain hypotheses. research locations to support the success of this study are the Office of the Regional Planning, Research and Development (BP3D) Boyolali Regency and the Office of Agriculture in Boyolali Regency:

\footnotetext{
${ }^{9}$ Ridwan HR, Hukum Administrasi Negara, UII Press, Cetakan Kedua, Yogyakarta, 2003, P.229

10 Soerjono Soekanto, Faktor-faktor Yang Memperngaruhi Penegakkan Hukum, Raja Grafindo Persada, Jakarta, 2007, P.2

${ }^{11}$ Soerjono Soekanto, P.3

12 Ateng Syafrudin, 1994.Butir-butir Bahan Telaahan Tentang Asas-asas Umum Pemerintahan Yang layak Untuk Indonesia, dalam Paulus Efendi Lotulung, Himpunan Makalah Asas-asas Umum Pemerintahan Yang Baik. Citra Aditya Bhakti, Bandung, P.64 
1. The data source in this study is direct. Boyolali Regency Office of Planning, Research and Development Agency (BP3D) and Boyolali Regency Office of Agriculture (Primary). Primary legal materials such as:

a. 1945 Constitution Article 33

b. Law No. 26 of 2007 concerning Spatial Planning

c. Law No. 41 of 2009 concerning the protection of agricultural land for sustainable food

d. Law No.1 of 2011 concerning Housing and Settlement Areas

e. Central Java Provincial Regulation No. 6 of 2010 concerning the Central Java Province Spatial Planning Plan for 2009-2029

f. Regional Regulation of Boyolali Regency No. 9 of 2011 concerning the Layout Plan of Boyolali Regency in 2011-2031

2. Data analysis techniques in which there are 3 main components of the data $:^{13}$

a. Data reduction: Form of making abbreviations, coding, focusing themes, making problem boundaries, writing memos

b. Data display: An assemblage of information organizations that allows research conclusions to be carried out.

c. Conclusion data

From the beginning of the data collection, the researcher must begin to understand the meaning of things that are found by recording the rules of patterns, statements, possible configurations, directives of cause and effect, and propositions that the competent researcher holds these things are not strong, meaning that they remain open.

\section{Discussion}

Spatial planning law based on Law No. 26 of 2007 concerning Spatial Planning which is dominated by the "planning system" - "spatial planning system from the top down", which causes losses and misery, which is not expected (economic, non-economic, non-economic-ecological, social aspects), because ignoring the principle of side by side, which starts spatial planning from the bottom up, namely from the Village Spatial Planning to the Village Spatial Planning, as a planning system in spatial planning, so that the spatial planning is "merely" a correction of the existing spatial layout for the purposes of emergency, for example priority in the interests of environmental security from floods and landslides. The principle of spatial planning basically requires regional planning (sectoral planning), money (investment) and time to be held at the same time

Spatial Planning, is the result of a government formed based on the will of the government known as the top down not on the initiative of the community or bottom up, which is the problem here because it was formed by the government while the root of the problem Indonesia does not yet have a single basic map, both national and regional. (Interview Results1).

From these conditions illustrate that the spatial system arrangement with the provisions that the community must follow the direction of the government.

In the case of the establishment of housing on the status of agricultural land, there is a new problem in Boyolali Regency. This needs to be addressed by concrete actions from the government. The proper arrangement and attitude in the case of the establishment of

${ }^{13}$ Setiono, op.cit., P. 30-32 
settlements in Boyolali Regency was stated by the Head of the District Agriculture Office. Boyolali with the following opinion:

Increasing land requirements in Boyolali Regency, so that the suburban area has potential and the existing land use has begun to shift for land tenure and / or land use (land use) of each sector in a constructive manner and there is no possibility of spatial planning and zoning that is stable or sustainable.

With regard to regional autonomy, the community must have a village spatial plan, which contains data, subjects and objects, therefore according to the legal status, a Regional Spatial Plan needs to be reviewed. Regarding this spatial plan related to the legal status of the land, whether state land, communal land or individual land. Regarding ulayat land, there is a bill, but until now it has not yet been made. This ulayat land is a customary land that contains cultural values and is a land that is owned for generations. (Interview Results 2).

Expansion of Agricultural Land and Adding New Agricultural Land as well as replacement of agricultural land used as an alternative to handling the problem of using agricultural land into settlements (Agricultural Extensification). By looking at a single base map (containing data and information) that overlaps, causing conflicts between districts and cities and even provinces, because it is based on PP No. 10 of 2000 concerning the Level of Accuracy of Maps for Regional Spatial Planning stipulates that for the spatial plan added $2.5 \mathrm{~km}$ for the district, for the province of $10 \mathrm{~km}$, if a conflict occurs, the area cannot be utilized either by the city or district and provincial government, conflict this is usually sourced from natural resources that exist between the boundaries of the area.

If related to subject and object data (area data), the law must be logical because at the first level the law is a positive law in this case the law and jurisprudence, this jurisprudence increases the need for land in the district. Boyolali, so that the suburban area has potential and the existing land use has begun to shift for land tenure and / or land use (land use) of each sector in a constructive manner and there is no possibility of spatial planning and zoning that is stable or sustainable.

With regard to regional autonomy, the community must have a village spatial plan, which contains data, subjects and objects, therefore according to the legal status, a Regional Spatial Plan needs to be reviewed. Regarding this spatial plan related to the legal status of the land, whether state land, communal land or individual land. Regarding ulayat land, there is a bill, but until now it has not yet been made. This ulayat land is a customary land that contains cultural values and is a land that is owned for generations. (Interview Results2) this aims to solve problems in positive law, then legal theory, which bridges to achieve national law, national law must be sustainable and sustainable, the philosophy of law to transform in achieving truth and supported by science and technology.

\section{Conclusion}

Agricultural development will occur if the problem of land over the conversion of agricultural land into settlements cannot be avoided or need to look for a solution to a problem that is very urgent, this is by studying the impact of the problem and socializing to the community over these impacts and their resolution. When land starts to shrink, domestic food needs will decrease because population growth cannot be avoided every year. For this reason, special handling is immediately needed, such as direct counseling for the community. Will the danger of land conversion is carried out continuously. And the development of the latest technology is needed to manage the land so that fertility does not 
decrease quickly so as to reduce land productivity. Another thing is in the form of replacing agricultural land which is used as an alternative handling of agricultural land conversion problems to obtain clarity of the land conversion legality.

\section{References}

Koestoer, Raldi Hendro. (1995). Perspektif Lingkungan Desa Kota: Teori and Kasus. Jakarta: UI. Press.

Pandapotan, S., and Silalahi, H. (2019). Social Capital as a Local Wisdom of Farmer in Managing Agricultural Resources in Lubuk Pakam Sub-district, Deli Serdang District. Budapest International Research and Critics Institute (BIRCI-Journal), 469476.

Ridwan HR, (2003). Hukum Administrasi Negara, UII Press, Cetakan Kedua, Yogyakarta.

Ridwan and Sodik. (2016). Hukum Tata Ruang dalam Konsep and kebijakan Otonomi Daerah. Cetakan Ke 3. Bandung: Penerbit Nuansa.

Rochimin, Dahuri et al. (2004). Pembangunan Wilayah: Perspektif Ekonomi, Sosial and Lingkungan. Jakarta: LP3ES.

Setiono, (2005). Pemahaman terhadap Metodologi Penelitian Hukum. Program Studi Ilmu Hukum Pascasarjana Universitas Sebelas Maret, Surakarta.

Soerjono Soekanto, (2007). Faktor-faktor Yang Memperngaruhi Penegakkan Hukum, Raja Grafindo Persada, Jakarta.

Taufiqurokhman. (2014). Kebijakan Publik. Fakultas Ilmu Sosial And Ilmu Politik Universitas Moestopo Beragama Pers. ISBN 602-9006-07-0. 